\title{
Impact of Leadership Styles on Teaching and Learning Process in Imo State
}

\author{
L.I Okoroji \\ Department Of Transport Management Technology, Federal University of Technology, Owerri \\ E-mail: okoroji_lazarus@yahoo.com

\section{O.J Anyanwu} \\ Department of Maritime Management Technology, Federal University of Technology, Owerri \\ E-mail: okey_god2002@yahoo.com
}

Wilfred I. Ukpere

Department of Industrial Psychology \& People Management, Faculty of Management University of Johannesburg, Email:wiukpere@uj.ac.za

Doi:10.5901/mjss.2014.v5n4p180

\begin{abstract}
The research examined the effect of leadership styles on teaching and learning process. The population comprises the academic staff of selected secondary schools in Owerri North Local Government Area (LGA). The academic staff members selected includes junior and senior staff members, as well as male and female staff. Sixty-six teachers, which constitute the population of academic staff of selected from secondary school makes up the sample for the study. Stratified random sampling technique was used for sample selection. Self structured questionnaire was the instrument used for data collection. The method of data analysis used on this research work is ANOVA statistics. Based on the summary of the findings, Gender to a high extent, influences the leadership style used in classroom teaching and learning process. The result also reveals that majority of secondary school teachers in Owerri North used democratic leadership style more than other types of leadership styles. Having listed some findings of the research work, it is necessary to make recommendation. Both male and female teachers should be exposed to constant and relevant seminars, workshop by the school management boards in order to ensure that these teachers are equipped with better understanding of leadership style as well as better combination of these styles.
\end{abstract}

Keywords: leadership style, Learning, Teaching

\section{Introduction}

Leadership has been observed as fundamental to the success of any group or organization. Therefore, leadership style in the classroom cannot be overemphasized in teaching and learning. It goes a long way in determining performance of both the teachers and the student or learner. It is the classroom teacher who is the boss, director, manager, administrator and organizer. He enjoys relatively higher degree of privacy and autonomy (Amadikwe 1991). Reasonable part of a teacher's life is spent in building peoples' knowledge, influencing the feelings and behaviours of pupils/students toward goal achievement.

The teacher's choice of career, professional training affects his/her skills, abilities and attitudes. The interaction between teacher and the student is one of the most important aspects of educational process, but the most neglected. Educational research reveals it through direct observation of teacher and students inside the classroom. Privacy and autonomy enable each teacher to manage and organize his own classroom the way he prefers to handle it.

\subsection{Statement of the problem}

The issues of leadership styles in teaching and learning have been raised in many instances, by trying to find out the causes of poor standard of education in Nigeria. It seem to be out of the mind that teachers' that leadership style in the 
classroom is an outstanding determinant of student academic performance. However, the improvement of pupils interaction and social skills are seen as important aims of education.

There is problem of management of classroom discipline which is one of the moral and ethical activities that enable pupils to improve their social and interactive skills. Classroom discipline management is an important but difficult aspect of teachers work. That is interaction between teachers and students is the most important aspect of educational process but most neglected.

It is also believed by many that male teachers are better in maintaining discipline in the classroom through the leadership styles. Even the problem posed by teachers training, experience in the colleges and universities, attended by the teacher's course taken, and the instructional experience during practice teaching, in-service and post graduate education. There is also a problem of centralized role in traditional classroom which should be shifted to more attentive teaching technique or behaviours.

Some leadership styles enhance teachers/pupil relationship why some impose dissatisfaction. It is necessary to determine how each of these leadership styles affect teaching and learning.

In the light of the above, there is need to find out solution to the problem of leadership style in teaching that have adversely influence the classroom, which may result to unproductive learning in the classroom.

\subsection{Objective of the study}

The purpose of this research is to:

- To find out the extent to which leadership styles contribute to teaching and learning in education.

- To identify the leadership styles mostly used by teachers in Owerri North LGA.

- To ascertain whether the sex of the teacher influences his leadership styles in the classroom.

- To determine whether teacher level of qualification and experience are important determinant of their leadership style.

\subsection{Research questions}

The following research questions were formulated to guide the study.

- Does leadership style contribute to teaching and learning in Education?

- What leadership styles are mostly used by teachers in Owerri North L.G.A?

- Does gender influence the leadership style of teacher in classroom teaching and learning process?

- Which levels of teachers' qualification have good leadership style?

\subsection{Research hypotheses}

Based on the objectives of the study and the stated research questions, two hypotheses were constructed to help address the research problem.

\subsubsection{Hypothesis 1}

- H0: Leadership style does not contribute to teaching and learning process in education.

- H1: Leadership style contributes to teaching and learning process in education.

Responses from question number five will be applied in testing the hypothesis.

\subsubsection{Hypothesis II}

- H0: Teachers qualification does not influences his leadership style in teaching and learning process.

- H1: Teachers qualification influences his leadership style to teaching and learning process.

\section{Leadership Defined}

Fullan (1998) states that, "Leadership is an essential element of parish life, which calls forth gifts of visioning, planning, empowering, and evaluating for the service of the community." Weihrich \& Koontz (1997) maintains that the ability to 
lead, including inspiring others is a shared vision. Leaders have clear visions and they communicate these visions to their employees. They foster an environment within their companies that encourages risk taking, recognition and rewards, and empowerment allowing other leaders to emerge..

\subsection{Concept of leadership}

Iwe (1991) states that, "group life or life in society is natural to man as leadership is a necessary attribute of social life in a society. Therefore, leadership helps to co-ordinate organizations. Iwe also outlined leadership qualities as "prominence of personality, superiority of ability, knowledge, experience, resourcefulness and courage and the ability to generate cooperation, stimulate initiatives, exert positive influence and inspire others". There are essential attributes necessary for the leader to command and elicit the support and co-operation of the lead for the realization of the goals of the organization. Adeshina (1980) opines thus "whether concept of leadership one prefers it must be admitted that leadership connotes the ability of getting things done with assistance and cooperation of the people within the institution or system".

Clark \& Clark (1994) observe that leadership is a process by which a person influences others to accomplish an objective and directs the organization in a way that makes it more cohesive and coherent. Leaders carry out this process by applying their leadership attributes, such as beliefs, values, ethics, character, knowledge and skills. Although your position as a manager, supervisor, leader, etc. gives you the authority to accomplish certain tasks and objectives in the organization, this power does not make you a leader, it simply makes you the boss.

Leadership differs in that it makes the followers want to achieve high goals, rather than simply bossing people around. Bass (1990) states that, there are three basic ways to explain how people become leaders. The first two explain the leadership development for a small number of people. There are various theories to explain leadership development. For instance the trait theory says that some personality traits may lead people naturally into leadership roles. A crisis or important event may cause a person to rise to the occasion, which brings out extraordinary leadership qualities in an ordinary person. This is known as the situational theory. People can choose to become leaders by learning leadership skills. This is referred to as the behavioral leadership theory. It is the most widely accepted theory today and the premise on which this study is based. When a person is deciding if she respects you as a leader, she does not think about your attributes, rather, she observes what you do so that she can know who you really are. She uses this observation to tell if you are an honorable and trusted leader or a self-serving person who misuses authority to look good and get promoted. Self-serving leaders are not as effective because their employees only obey them, not follow them. They succeed in many areas because they present a good image to their seniors at the expense of their subordinates.

\subsection{Factors in leadership}

Clark \& Clark (1992) noted that there are four major factors in leadership. Firstly different people require different styles of leadership. For example, a new hire requires more supervision than an experienced employee. A person who lacks motivation requires a different approach than one with a high degree of motivation. The fundamental starting point is having a good understanding of human nature, such as needs, emotions, and motivation. A leader must know his employees. Secondly, a leader must have an honest understanding of who his subordinates are, what they know, and what they can do. Thirdly, a leader should lead through two-way communication. Much of it is nonverbal. Finally, what a leader does in one situation will not always work in another. Therefore, a leader must use your judgment to decide the best course of action and the leadership style needed for each situation. For example, a leader may need to confront an employee for inappropriate behavior, but if the confrontation is too late or too early, too harsh or too weak, then the results may prove ineffective.

\subsection{Theories of leadership}

Sullivan \& Decker (1997) state that there are eight basic types of leadership theories, which can be distinguished based upon the question they are designed to answer. The first is the 'Great Man or trait theories of leadership', which addresses the specific question "What is a leader?" This theory answers the question by specifying or identifying traits, characteristics, abilities, behavioral patterns or skills that leaders possess (Robin \& Judge, 2009). If a definition is offered by a trait theorist, it normally begins "a leader" and follows with a list of traits (is a servant, is charismatic, is ethical, takes initiative, shows excellence, is goal-oriented, is inspiring, is good at communicating, has positive self-regard, is empowering, etc. The next one is 'Management (Supervision) theories of leadership', which addresses the specific 
question "How do leaders get people to do what they want them to do?" These theories are concerned primarily with organizational or group performance. This type of theory (transactional leadership, transformational leadership, democratic leadership, path-goal, etc. tends to dominate leadership thought and discussions of "different" theories are usually limited to this type. The essential problem for these theories is the problem of exploitation. Marx substantiated that capitalism can only work if workers are paid less than they are worth (Ukpere, 2007). If they are paid according to their worth, there is no profit for owners. Management theorists undertake two important missions: (1) to justify the superiority of the leader, and (2) to get people to accept their role in the economy by inspiration, coercion, and exchange of values, conformance etc., and thereby accepting their subsequent exploitation.

The next one is 'Relationship theory', which answers the question by defining leadership as a relationship among people with mutual wants and needs who are striving for mutual goals (no one goes to work to make someone else rich). However, Process theory answers the question by defining leadership as a process of dynamic interaction among people with varying ethics who align themselves to solve specific social problems or to generate general evolutionary social change (Roa, 2009). This process is understood as dissipative and not controllable by the leader. In these theories, the leader is more of a symbol of what everyone wants rather than a producer of outcomes. The fundamental problem for leadership studies is distinguishing leadership from management, supervision, statesmanship and command. All of these words represent concepts that are different, but often labeled "leadership". Another theory is the "Participative leadership theory', which is a leadership styles that involve other people in the leadership process. These theories do suggest, however, that a leader retains the right to give or deny any subordinate a say in the leadership process (Prasad, 2004). However, Situational leadership theory suggests that leadership is specific to the situation in which it is being exercised. These theories involves normative model, action-centered leadership model, Hersey and Blanchard's situational leadership model, path-goal theory, suggest that there may be different styles of leadership required at different levels in the same organization (Arnold \& Ukpere, 2012). Finally contingency theory refines the situational viewpoint by focusing on identifying the situational variables that determine the most appropriate style of leadership to fit the particular circumstances (Kumar, 2000).

\subsection{Teacher Leadership}

The principals play a key role in developing teacher leadership. To identify, develop and support teacher leaders in their schools, principals should define teacher leadership, encourage teachers to become leaders, help teachers develop leadership skills and provide positive and constructive feedback (Wynn, 2001). Schools run by committees of teachers, without an administrator is a case in point. Wynn (2001) says most of the researchers involved in exploring the concept of teachers as leaders agree that it is distinctly different from administrative or managerial concepts of leadership.

\subsubsection{Leadership roles of teachers}

Davidhizar \& Cramer (2000) maintained that there have long been formal leadership roles for teachers as department chairs, team leaders and a variety of other positions, but titles are less important than actually functioning as effective change-agents. Teachers exhibit leadership by: Participating in professional teacher organizations, including holding positions of influence; Making student and adult learning the priority; Setting high expectations for performance; Gearing content and instruction to standards; Creating a culture of continuous learning for adults; Using multiple sources of data to assess learning; Activating the community's support for school success; Taking part in school decisions, including working on teams with administrators to plan school improvements; Defining what students need to know and be able to do, including developing standards for curriculum and assessments; Sharing ideas with colleagues, including leading professional development programs for colleagues; Being a mentor to new teachers. Helping to make personnel decisions, including the hiring of new teachers and administrators; Improving facilities and technology; Working with parents, including the development of better links between schools and homes; Creating partnerships with colleges and universities to prepare future teachers; Becoming leaders in the community, and Leading efforts to make teachers more visible and communicate positive information.

\subsubsection{Teacher leadership attributes}

Clark (1997) maintains that if a person is a teacher leader that can be trusted, then people will grow to respect him. To be such a teacher leader, there is a Leadership framework to keep in mind. A teacher leader should be a professional who 
is loyal to the organization, perform selfless service, take personal responsibility; possess good traits such as honesty, competence, candor, commitment, integrity, courage, straightforwardness, imagination). A teacher leader should know the four factors of leadership follower, leader, communication, and situation, in addition to his strengths and weakness, character, knowledge and skills. It is also important for him to understand the human nature, such as human needs, emotions and how students respond to stress. A teacher leader must also know his job, namely he should be proficient and be able to train others in their tasks. He should as well know his institution such as where to go for help, its climate and culture. A teacher leader should provide direction, namely goal setting, problem solving, decision making and planning. He should also be able to implement goal through effective communication, coordination, supervision and evaluation. He should also be a powerful motivator by boosting the moral and spirit of people in the institution through training, coaching and counselling (Ukpere \& Naris, 2012)

Good \& Brophy (1995) have identified some general attributes of teachers that contribute to their success in socializing students. These attributes include: Social attractiveness, based on a cheerful disposition, friendliness, emotional maturity, sincerity and other qualities that indicate good mental health and personal adjustment. Ego strength, exhibited in self-confidence that allows teachers to be calm in a crisis, listen actively without being defensive, avoid winlose conflicts and maintain a problem-solving orientation. Realistic perception of self and students, without letting perceptions become clouded by romanticism, guilt, hostility or anxiety. Enjoying students while at the same time, maintaining their identity as an adult, a teacher and an authority figure. It is good to be friendly but not overly familiar. It is also important to be comfortable with the group without becoming a group member. Clarity about teacher's role, and comfort in playing them, enables teachers to explain coherently to students what they expect. It is necessary to be patience and determined to work with students who persist in testing limits. Acceptance of individual, though not necessarily all of his or her behavior, and making this attitude clear to students. The ability to state and act on firm but flexible limits based on clear expectations is another perquisite. It is also important to keep rules to a minimum and liberalizing them as students become more independent and responsible over time. Developing these personal qualities and using research-based principles for managing the classroom will set the stage for student socialization and will go a long way toward minimizing the need for disciplinary interventions.

\subsubsection{Teacher leaders and positive learning climate}

Larry (1998) observes that learning climate is a concept that is easy to recognize but difficult to define. Some definitions emphasize setting high expectations while others highlight friendliness or "organizational personality. There is a consensus, however, that the principal is the key. Discussions of climate have often focused on individual administration initiatives such as minimizing outside intrusions into classroom time, roaming the hallways to greet students personally, and dispensing rewards for achievement. The move toward collaboration reveals a much more complex process. Sergiovanni (2001) whose concept of "community" encompasses most of the dimensions of climate identifies relationships as the linchpin. In a true school community, relationships are based on shared values rather than bureaucratic roles, resulting in individuals who care, listen, understand, respect others and are honest, open and sensitive." He concedes that principals may need to begin by using bureaucratic authority but must ultimately build relationships based on professional and moral authority.

\subsection{Leadership styles in teaching learning process}

Atchison and Hills (1978) has described autocratic leadership styles by stating that "the autocratic leader is in the centre of an organization, production oriented and efficiency minded who gives firm directive, sets control and expects compliance". He makes decision alone by its own authority and expects his followers to carry them out without questioning. Under this type of leadership style, certain contribution originating from the subordinates which enhance the growth and over all development of the system one disregarded. He regards himself as the sole native agent in the administration set up and considers his subordinates as passive receivers of the instructions, information and knowledge. The leadership in this case is often characterized by nagging, distrust and suspension. This is normally due to lack of effective communication between the leader and subordinates. This situation gives room to rumours, poor management, black mailing and sycophancy in the organization

Atchison and Hill (1987), describe these styles of leadership as "hardly being a teacher of all since it tends to let things get done. Such a person may seem to be absent even when physically present. He has little or no effort to affect the situation". Brawn (1989) opines that, this modal of leadership is characterised by indecision and indifference. The 
leader seldom has a clear vision of organizational goals and develops no policies or programmes. He allows completes freedom to the group and individual member to do as they wish. This type of leadership style lacks focus and direction. And the teacher is always in a dilemma when situation demanding crucial decision crops up.

Fred (2001) stated that in a democratic system the students are surely involved in any efforts aimed at finding solution to the problems and planning the classroom of the organization. The leader in this style makes for easy flow of information to dispel remours and also provide avenue of steady feedback mechanism. Vain (2000) emphasized that a democratic leader does not normally takes arbitrary orders and decision as he regards the subject as partner in progress. $\mathrm{He}$ is always mindful and sensation to the needs and welfare of the staff and strives always to motivates them.

A teacher with democratic leadership style employs guidance in decision making, especially decision affecting his class by giving paramount attention their feelings by sharing information and creating a pleasant working relation in the classroom. Kojo (2001) avers that that "in conflict management and resolution, the democratic leader will usually employ wide consultation, dialogue, persuasion and above all, compromise as veritable tools for achieving a stable and enduring tranquility within the system". At all times, the democratic leader makes available his advice and suggestion to his class.

\subsection{Gender and leadership style}

A work sheet on leadership style was developed by Mac Gregory (2002) on gender differences. How things are done in organizational structure, men see increase member participation in decision making as a breakdown of their influence. While participation by all members, is the philosophy for women leader. Men prefer a competitive response to conflict which is frequently seen as a "win or lose" approach, while women leaders work with others to resolve conflict and seek to find different and more satisfying to complex problems rather than those proposed by either side.

According to Eagly and Johnson (1990) two findings were consistent across all studies, namely that women were more participative or democratic in their leadership style than men who were more directive or autocratic leaders. In laboratory and assessment studies female leaders showed more concern with the maintenance of interpersonal relationship and male leaders displayed more task-oriented behaviours. The meta-analysis also showed the influence of the gender type of the role and leaders task orientation (Eagly and Johnson, 1990). In roles considered to be male, men displayed some female characteristics, such as those requiring "considerable interpersonal ability", and women leaders showed some more task oriented behaviors. Rosener (1990) ascertains that men's styles were found to be consistent with transactional leadership while women's leadership and influence styles to consistent with participatory style (Rosener, 1990). He attributes this to their socialization and the career paths they had chosen. Bass (1990) stated that, "the preponderance of available evidence, particularly from field studies is that no consistently clear pattern of differences can be discerned in the supervisory styles of female and male leadership".

\subsection{Initiating leadership style or directive behavior (task orientation)}

Initiating structure is defined, as the degree to which a leader defines and organizes his role and the roles of students. He is oriented toward goal attainment and establishes well-defined patterns and channels of communication. Leaders believe that they get results by consistently keeping people busy and urging them to produce. This reflects how much a leader is concerned with the actual task at hand and ensuring that those following him complete it (Schriesheim, 1982). Some behaviors of leaders who are strong in initiating structure style include: Letting students know what is expected of them; Encouraging the use of uniform procedures; Trying out ideas in the class; Making his/her attitudes clear to the class members; Deciding what shall be done and how it shall be done; Assigning particular tasks to class members; Scheduling the work to be done; Maintaining definite standards of performance and requesting the class members follow standard rules and regulations

\subsection{Consideration leadership style or supportive behavior (students orientation)}

Consideration is defined as the degree to which a teacher leader shows concern and respect for students, looks out for their welfare, and expresses appreciation and support. Leaders are concerned about the human needs of their students. They build teamwork, help students with their problems and provide psychological support. This reflects how much a leader is concerned for the people around him, providing support and encouragement for them (Schriesheim,, 1982). Some behaviors of teacher leaders who are strong in consideration style include: Friendliness and approachable; Operationalising suggestions from students; Treating all students as equal; Giving advanced notice of changes; Making 
him/herself accessible to students; Looking out for the personal welfare of students; Willingness to make changes; Explaining actions and Consulting the pupil when making changes. There is evidence that teachers who are considerate in their leadership style are higher performers and are more satisfied with their job (Schriesheim, 1982). Schriesheim (1982) also notice that consideration and structure are not independent of each other, thus they should not be viewed on opposite ends of a continuum. For example, a teacher leader who becomes more considerate does not necessarily mean that she has become less structured.

\subsection{Teacher leaders and student academic performances}

According to Wynne, (2001) the ultimate measure of the contributions of teacher leaders, proponents suggest is the impact of teacher leaders on student academic performance. Many scholars assume that the one causes the other (Lieberman, 1992). Nevertheless, a study by Leithwood and Jantzi (1999) indicates that while a multitude of qualitative studies suggest the efficacy of teachers as leaders, few quantitative studies have tested this notion. Leithwood's (1999) study, involving a sample of 1,762 teachers and 9,941 students in a large Canadian School district, not only found no impact of teacher leadership on raising student achievement, but also hypothesized that by trying to combine leadership with teaching, teaching is devalued. Barriers such as too little time during the work day for reflection, rigid school schedules, unrelated instructional tasks, jealousies and/or lack of support from peer teachers and administrators and overemphasis on state mandated high-stakes testing, hamper the effectiveness of many teachers who, while teaching, step beyond their classrooms to lead

\subsection{Teacher leadership and students motivation}

According to Katzenmeyer \& Moller (1996) here is a few other steps school leaders can take to improve student motivation at the school level: Analyze the ways that motivation operates in your own life and develop a clear way of communicating it to teachers and students. Seek ways to demonstrate how motivation plays an important role in no educational settings, such as in sports and in the workplace. Show students that success is important. Recognize the variety of ways that students can succeed. Reward success in all its forms. Develop or participate in in-service programs that focus on motivation. Involve parents in discussing the issue of motivation and give them guidance in fostering it in their children. Demonstrate through your own actions that learning is a lifelong process that can be pleasurable for its own sake.

\subsection{Leadership development}

According to Davidhizar \& Cramer (2000), "there have been a variety of formal approaches to cultivating leadership among teachers and no one approach has emerged as the most effective in all situations. Examples of teacher leaders were found to span the spectrum from classroom teachers who demonstrate and model new techniques within their own classrooms to highly proactive "change agents" who challenge, inspire, and motivate colleagues to initiate school wide change. In their study of 354 teacher leaders participating in 15 two-year professional development programs, Nesbit, DiBiase, Miller, and Wallace (2001) analyzed evaluation reports and conducted interviews. They found three broad categories of factors to be most influential in supporting the development of leadership roles:

1. Factors related to knowledge of content and pedagogy, including learning in-depth content through hands-on activities, learning instructional strategies, and learning about curriculum resources.

2. Factors related to the modes of professional development, from receiving curriculum materials to observing teaching and leadership techniques, receiving ongoing support from a professional development staff, and analyzing a school's strengths and weaknesses. Factors related to the development of leadership skills, both through learning about leadership skills (i.e. presentation skills, team-building skills) and concepts (i.e. the change process, adult development), and through planning and practicing leadership skills. This could include working with other teacher leaders on instruction, resolving leadership challenges, becoming familiar with school improvement plans, or role playing.

They further noted that the first two broad categories are typically addressed in professional development programs, and their importance is well supported by the literatures in the field. The unique contribution of this study is the clear identification of explicit development of leadership skills as being a key component in cultivating teacher leader. There is little research identifying the essential elements of this component, however, and it is often neglected in teacher 
leader development programs. In stating some of the core expectations of teacher leaders, there are some dimensions for leadership skill development. Teacher leaders are expected to: Demonstrate exemplary classroom instruction and knowledge of effective strategies for teaching and learning; Understand theories of adult development; Demonstrate knowledge of clinical supervision models and procedures that promote effective classroom practices; Cultivate desired dispositions among teachers; Guide colleagues through reflective and inquiry-oriented techniques; Possess researchbased knowledge about teaching and learning; Teacher leaders must develop expertise in organization design, change theory, adult learning, management skills, decision-making, public relations and handholding.

\section{Research Methodology}

The area of study is Owerri North in Imo State. Imo State is made up of twenty seven local Government Area in which Owerri North is one of them. Geographically the state lies within Latitudes $4^{0} 45^{\prime} \mathrm{N}$ and $7^{0} 15^{\prime} \mathrm{N}$ and longitude $6050^{\prime} \mathrm{E}$ and $7025^{\prime} \mathrm{E}$ and covers an area roughly $5,100 \mathrm{sq} \mathrm{km}$. The region has an average annual humidity of $75 \%$ with humidity reaching $90 \%$ in the raining season. This area was chosen for purpose of an effective and more detailed research on leadership style in teaching and learning process.

\subsection{Population of study}

The research population comprised the academic staff of selected secondary school under study. The academic staff selected include junior and senior staff, Male and female Staff. The available data from the school administration shows that there are ten public secondary schools in Owerri North with two hundred and twenty six academic staff that makes up the population (School Administrators (Principal) 2011/2012).

\subsection{Sample and sampling techniques}

Sixty six teachers which constitute the population of academic staff of selected secondary school make up the sample for the study. Stratified random sampling technique was used for sample selection. The already existing strata were the academic staff of Girls Secondary School Akwakuma, Egbu Girls Secondary School and Naze Secondary School.

\subsection{Sample size}

\begin{tabular}{|c|c|c|c|c|}
\hline Schools & Number of teachers & Male & Female & Total \\
\hline Girls Secondary School Akwakuma & 24 & 10 & 14 & 48 \\
\hline Egbu Girls Secondary School & 22 & 8 & 14 & 44 \\
\hline Naze Girls Secondary School & 20 & 8 & 12 & 40 \\
\hline Total & 66 & 26 & $\mathbf{4 0}$ & 132 \\
\hline
\end{tabular}

Source: School Administrator (Principals) 2012.

\subsection{Method of data analysis}

The method of data analysis technique use on this research work is ANOVA Statistics. ANOVA is based on a comparison of the amount of variation in each of the treatment to the next significantly high. It can be concluded that treatment have dissimilar effect on the population.

- The total variation, which in variation among total number of all "n" observations.

- Within sample variation which is variation within any one given treatment (sample)

- Between the sample variation, which is variation between the treatment (sample)

It is by comparing these different sources of variation that ANOVA can be used to test for the equality in means of different population. The total variation caused by the different treatment plus the treatment on sample. That is:

Total variation $=$ Treatment (sample) variation + Error variation. To test the quality of population means the use of the sums of square of either types of variation namely:

i. Total sum of square (TSS)

ii. Treatment sum of squares (TRSS) and 
iii. Error sum of squares (ESS) where

$$
\text { ESS }=\text { TSS }=\text { TRSS }
$$

The formular for the variation sum of square are as follows

$\mathrm{TSS}=\mathrm{Ex}^{2} \frac{(\mathrm{E} \bar{x})^{2}}{\mathrm{n}}$

Where $E x^{2}=$ Being the sum of square of all measurement

$(E \bar{x})^{2}=$ the total number of all measurement square

$n=$ The total number of observation for all sample.

Therefore $=$ TRSS $=\left(n^{1} \bar{x}^{2}+n_{2} \bar{x}_{2}{ }^{2}+n_{3} \bar{x}^{2}{ }_{3}-n_{1} \bar{x}_{n}{ }^{2}\right)$

Freedom $=(E n) 2$ has $\frac{(r-1)}{n}$ degree of

TRSS $=E n,(x-\bar{x})^{2}$

Where $\mathrm{nj},=$ Being total number of individual sample.

$\mathrm{Xj}=$ Being individual mean of each sample or observation

$\mathrm{N}=$ Total number of observation for all sample

$X^{2},=$ sum of mean squared also called grand mean

The treatment sum of square has $(r-1)$ degree of freedom

$\mathrm{ESS}=\mathrm{TSS}=\mathrm{TRSS}$

This has $(n-1)-(r-1)=n-r$ degree of freedom.

\section{Analysis and Interpretation}

\subsection{Testing hypothesis 1}

- H0: Leadership style does not contribute to teaching and learning process in education.

- H1: Leadership style contributes to teaching and learning process in education.

Responses from question on four Likert scale will be applied in testing the hypothesis.

\begin{tabular}{|c|c|c|c|c|c|}
\hline Level & Agreed & Strongly Agreed & Disagreed & Strongly Disagreed & Total \\
\hline 0-7 staff & 4 & 5 & 2 & 3 & 6 \\
\hline 8-12 staff & 8 & 13 & 3 & 2 & \\
\hline 13-17 staff & 6 & 10 & 2 & 10 & 64 \\
\hline Ex & 19 & 28 & 7 & 3.33 & \\
\hline X & 6.33 & 9.33 & 2.33 & 121 & 548 \\
\hline Ex $^{2}$ & 116 & 294 & 17 & & \\
\hline
\end{tabular}

$\mathrm{TSS}=\frac{\mathrm{Ex} 2-(\mathrm{Ex}) 2}{\mathrm{n}}$

$=548-\frac{(64)^{2}}{12}$

$=548-341.33$

TSS $=206.67$

TRSS $=n_{1} x_{1}^{2}+n 2 x_{2}^{2}+\ldots \ldots \ldots . . . n_{4} x_{4}^{2}-\frac{(E X)^{2}}{n}$

$3(6.33)^{2}+3(9.33)^{2}+3(2.33)^{2}+3(3.33)^{2}-\frac{(64)^{2}}{12}$

$3(40.069)+3(87.049)+3(5.428)+3(11.089)=\frac{4096}{12}$

$120.21+261.15+16.287+33.267=341.33$

$=430.914=341.33$

TRSS $=89.584$

ESS $=$ TSS - TRSS

$=206.67-89.584$

ESS $=117.09$

Degree of freedom

TRSS = R - 1 


$$
\begin{aligned}
& =4-1=3 \\
& \begin{aligned}
\mathrm{TSS}=\mathrm{n}- & 1 \\
& =15-1 \\
& =14 \\
\mathrm{ESS}=\mathrm{TSS} & -\mathrm{TRSS} \\
& =14-3=11 \\
& =11
\end{aligned}
\end{aligned}
$$

Anova Table

\begin{tabular}{|c|c|c|c|}
\hline Source of variation & Degree of freedom (DF) & Sum of square (SS) & Mean of square (MS) \\
\hline Treatment & 3 & 89.584 & $\frac{89.554=29.86}{3}$ \\
\hline Error & 11 & 117.09 & $\frac{117.09=10.64}{11}$ \\
\hline Total & 14 & 206.69 & \\
\hline
\end{tabular}

$\mathrm{F}$ cal $=$ TRMS (Treatment mean square)

EMS Error mean square

$=\frac{29.89}{10.64}=2.81$

$\mathrm{F}_{0.05,3,11}=2.7$

\subsubsection{Decision}

Since the calculated $F$ value of 2.81 is greater than table $F$ value of 2.7 . We reject the null hypothesis and conclude that leadership style contribute to teaching and learning process in education.

\subsection{Testing hypothesis II}

- HO: Teachers qualification does not influences his leadership style in teaching and learning process.

- H1: Teachers qualification influences his leadership style to teaching and learning process.

Responses from question number nine will be in applied testing the hypothesis.

\section{Table 3:}

\begin{tabular}{|c|c|c|c|c|c|}
\hline Level & Agreed & Strongly Agreed & Disagreed & Strongly Disagreed & Total \\
\hline To academic staff & 2 & 2 & 8 & 8 & \\
\hline Middle academic staff & 3 & 6 & 9 & 12 & \\
\hline Low academic staff & 2 & 3 & 3 & 6 & \\
\hline Ex & 7 & 11 & 20 & 26 & 64 \\
\hline XXXyyyyy & 2.33 & 3.7 & 6.7 & 8.7 & \\
\hline Ex $^{2}$ & 17 & 49 & 154 & 244 & 464 \\
\hline
\end{tabular}

$$
\begin{aligned}
\text { TSS } & =\frac{\text { Ex2 }-(E x) 2}{n} \\
& =464-\frac{(64)^{2}}{12} \\
& 464-341.33 \\
& \text { TSS }=122.67 \\
& \text { TRSS }=n_{1} x_{1}^{2}+n_{2} x_{2}^{2}+\ldots \ldots \ldots . . n_{4} x_{4}^{2}-\frac{(E X)^{2}}{n} \\
& 3(2.33)^{2}+3(3.7)^{2}+3(6.7)^{2}+3(8.7)^{2}-\frac{(64)^{2}}{12} \\
& 3(5.42)+3(13.69)+3(44.89)+3(75.69)=\frac{4096}{12} \\
& =16.26+41.07+134.67+227.07=341.33 \\
& =419.07=341.33
\end{aligned}
$$




$\begin{array}{lll}\text { TSS } & = & 77.74 \\ \text { ESS } & = & \text { TSS - TRSS } \\ \text { ESS } \quad= & 44.92-77.74 \\ \text { Degree of freedom } & \\ \text { TRSS }=\mathrm{R}-1 & \\ =4-1 & \\ =3 & \\ \text { TSS }=\mathrm{n}-1 & \\ =15-1 & \\ & =14\end{array}$

Anova Table

\begin{tabular}{|c|c|c|c|}
\hline Source of variation & Degree of freedom (DF) & Sum of square (SS) & Mean of square (MS) \\
\hline Treatment & 3 & 77.74 & 25.91 \\
\hline Error & 11 & 44.92 & 4.08 \\
\hline Total & 14 & 122.67 & \\
\hline
\end{tabular}

$$
\begin{aligned}
F_{\text {cal }}= & \frac{\text { TRMS }}{\text { EMS }} \frac{(\text { Treatment mean square })}{\text { Error mean square }} \\
= & \frac{25.91}{4.08}=6.35 \\
& F_{0.05,3,11}=2.7
\end{aligned}
$$

\subsubsection{Decision}

Since the calculated $F$ value of 6.4 is greater than table $F$ value of 2.7. We reject the null hypothesis and conclude that teachers' qualification does influence his leadership style in teaching and learning process.

\section{Discussion of the Findings}

\subsection{The effect of leadership style on teaching and learning process in education}

The findings from the research question shows that, large numbers of teachers make prudent application of leadership style in teaching and learning process in every classroom environment. This contributes to student academic performance to some extent. This was shown by 28 respondents representing $43.8 \%$ of teachers in Owerri North, ranked highest out of a sample size of 64. This finding agrees with Onoyese (1991) who says that the type of leadership that exists between leaders and the lead is an important variable that contribute to the success or failure of an organization.

However, majority of the teachers in secondary school in Owerri North also accept that leadership styles contribute to teaching and learning process to a high extent for the achievement of desired educational goal and objectives. This rated first as 30 respondent representing $46.9 \%$ agreed out of sample size of 64 . It was also shown that in Owerri North L.G.A secondary school teachers apply leadership style in their teaching and learning process by large percentage, 28 respondent representing $43.7 \%$ agreed out of the sample size of 64 .

\subsection{The leadership style mostly used by teachers in Owerri North L.G.A}

The result revealed that majority of secondary school teachers in Owerri North uses democratic leadership style more than other types of leadership styles. It is shown that 30 respondent representing $46.9 \%$ of teachers of a sample of 64 apply or used democratic leadership style in teaching and learning process. This is seen in teachers-pupils relationship in teaching and learning process, which agrees with Oku (2006) which says that democratic leadership style encouraged class participation in decision making. The student seems to be satisfied with it because it gives them sense of belonging and recognized the worth as people that can contribute to the success of the classroom. 


\subsection{Influence of gender on leadership style in teaching and learning process}

Gender to a high extent, influences the leadership style used in classroom, teaching and learning process, with 29 respondent representing $45.3 \%$ out of the sample of 64 accepted to a great extent. This agrees with the finding of Rosener (1990) and other researchers who found mean style as transactional, and describes women style as participatory, which comes naturally from them frequently than men.

Again, 20 respondent representing $31.2 \%$ agrees that female teachers apply more than their male counterparts the best leadership style (democratic) in teaching and learning process. This supports the findings of Eagly and Johnson (1990) which says that women were more participative or democratic in their leadership style than men who were more directive or autocratic.

\subsection{Level of teachers qualification that have good leadership style}

From the finding, 26 respondent representing $40.6 \%$ of the sample of 64 shows that the levels of a teachers' qualification results in good leadership style and apply it in their teaching and learning process. These are teachers who do not agree with this. They rated second that is, 21 respondent representing $32.8 \%$ out of the sample of 64 . This teacher maintained that it is the grade level determines the leadership style adopted. For instance, they stated that 8-12 grades apply good leadership style in teaching and learning process.

\section{Conclusion}

In conclusion the following findings were identified in this study:

- Leadership style of a teacher contributes to the success of teaching and learning process for the achievement of the desired educational goals and objectives. This is because the leadership style between the teacher and the student is an important variable that contribute to acquisition of knowledge.

- The leadership style mostly used by teachers in Owerri north is democratic leadership style which is the best leadership in classroom teaching and learning. This improves student performance through the encouragement of class participation in decision making.

- It was also discovered that more women or female teacher are democratic than male teachers who are more autocratic. Democratic leadership style brings about good student teacher relationships.

- Finally, every level of qualification was discovered to be applying the appropriate leadership style in their classroom teaching and learning process in order to achieve the desired out come.

\subsection{Educational implication of the Study}

- From the finding so far it is imperative for a secondary school teacher to adopt an acceptable leadership style in order to become effective teacher since it makes an impart in the educational system. This is because ineffectiveness of teacher will contributes to failure in educational performance of the student.

- In a situation where the teacher is autocratic, the tendency is that some student may out of fear be unconfident. The teacher who uses this style may run the risk of loosing the genuine trust and co-operation from his students likewise the laissez-affair leadership style which allows the student to do things their way. This will lead to student to dislike academic activities and total failure in student academic performance. It implies that every teacher should apply the best leadership style that suits every teaching and learning situation.

- The leadership style used by male and female teachers affect the result in teaching and learning process. Therefore both genders should make prudent application of leadership style in every classroom climate, in order to achieve the goals and objectives of teaching and learning.

- As regards educational qualification of a teachers not being at the same level, every level of teacher should be taught how to apply best method of leadership style in classroom teaching and learning process. Nevertheless every level of teacher should be given opportunity to attend seminars and workshops etc to improve their ability in controlling and maintaining classroom activities (adequate classroom management).

In conclusion it could be said that without the right application of leadership style in teaching and learning process, there will be poor academic performance which have great adverse impact in educational system. 


\section{Recommendations}

Having listed the findings of the research work, it is necessary to make the under listed recommendations. Based on the above findings the following recommendations are made:

- Since leadership style of a teacher in secondary school contribute to achievement of educational goals and objective through teaching and learning process, the best leadership method should be applied as demanded by situation in the classroom by all teachers.

- Every secondary school teachers should be able to know the best leadership style to apply. This will contribute to the success of academic performance of students. It is achieved by allowing the student to actively participate in the classroom teaching and learning process.

- Both male and female teachers should be exposed to constant and relevant seminars workshop by the school management board in order to ensure that this teachers are equipped with better understanding of leadership styles as well as a better combination of this styles.

- However since educational qualification of teacher are not at the same level, every qualification level of teacher should be well trained during their professional training on how to manage and organize a classroom. This will enable every level of teacher to be able to maintain classroom discipline during the teaching and learning process.

\section{Reference}

Adeyoino, C. (1987) Teachers and their classroom planning. Ibadan: Oxford Publishers.

Adestina, V. (1980) Leaders in organization loges. Lagos: Adio Bode.

Akani, R. (1980) "The need to organize a classroom for effective learning and teaching. Ibadan: New Nigeria Publishers.

Arnold, N.H. \& Ukpere, W.I. 2012. Leadership Model for Appraising Employees' Readiness within Solidarity Trade Union in South Africa. African Journal of Business Management, 6(35): 9814-9822.

Atchison J \& Hills WW (1978) Management today, managing work in organization. New York: Harcourt.

Awa, U.C (2002) Planning classroom for efficient Teacher-pupil Relationship. Owerri: Column Books.

Bass, B. (1990). From transactional to transformational leadership: Learning to share the vision. Organizational Dynamics, 18: 19-36.

Brown, J.P and Phelps, D.A (1992). Managing the classroom: teachers Profession in School Administration. Chicago: Ronald Tress Company.

Clark, S. N., \& Clark, D. C. (1992). School restructuring: A leadership challenge for middle level administrators. In S. Clark \& D. Clark (Eds.), Schools in the middle: A decade of growth and change (pp. 200-207). Reston, VA: National Association of Secondary School Principals.

Clark, S. N., \& Clark, D. C. (1994). Restructuring the middle level school: Implications for school leaders. Albany , NY : State University of New York Press.

Clark, D. (1997, May 11). Concepts of Leadership. [Online] Avaliable: http://www.nwlink.com/ donclark/leader/leadcon.html [Retrieved on 3 April 2006].

Clark, D. (1997, May 11). Concepts of Leadership. [Online] Avaliable: http://www.nwlink.com/ donclark/leader/leadtem.html [Retrieved on 11 April 2006].

Crals, C. (1992). Psychology and Teaching. Scott: Foreman and Company.

Davidhizar, R., \& Cramer, C. (2000). Gender differences in leadership in the health Professions. Health Care Manager, 18(3), 18-24.

Eagly, A.H. \& Johnson, B.T. (1990). Gender and leadership style: A meta-analysis. Psychological Bulletin, 108, $233-256$.

Fred, YL (2001) Looking into the classroom. New York: Hamper and Row Publishers.

Good, L. T, \& Brophy, J. (1995). Contemporary educational psychology (5th ed.). New York, Longman Publishers.

Good, L. T, \& Brophy, J. (2009). Using Advance Organizers to Enhance Students' Motivation in Learning Biology Hudson Shihusa and Fred N. Keraro Egerton University, Egerton, KENYA. Eurasia Journal of Mathematics, Science \& Technology Education, 2009, EURASIA ISSN: $1305-8223$

Good, CV \& Marker, W.R (1982) Dictionary of Education. New York: McGraw Hill Company Inc.

Mac Gregory M (2002). Leadership 101: Developing leadership skills for resident youth, facilitators guide. Youth leadership.com, Page 79

Iroegbu, I. (1997), Democratic Leadership Style and the autocratic organization. Ibadan: Oxford Publishers.

Iwe, NSS (1991) Socio-ethnical issues in Nigeria. Enugu: Obasi Pacific Publishers

Jordan, R.S. (1998). Government and Power West Africa. Benin: Ethope Publishing Co. (Related project work, personal collection)

Katzenmeyer \& Moller, (1996). Teacher Leadership, Collective Efficacy, and trust. [Online] Avaliable: http://www.elps.utk.edu /faculty_staff/ce.tl.trust.11.19.11.pdf [Retrieved 14 June 2012].

Kojo, O. (2001). Integrating the Nigeria Teacher: The New approach to teaching. Warri: Human books.

Kumar, P. (2001). Personnel Management and Industrial Relations. Meerut: Kedar Nath Ram Nath. 
Leithwood K \& Jantzi D (1999). The effects of transformational leadership on organizational conditions and student engagement with schools. Journal of Educational Administration, 38(2):112-129. (Related project work, personal collection)

Lieberman, A. (1992). Practices that support teacher development: Transforming conceptions of professional learning. Science Education: NSF Evaluation Forums 1992-94, 1995-nsf.gov

Lipman, P (1998). Academic enrichment through students leadership and Community outreach. [Online] Available: www.gmu.edu.6060 [Retrieved 3 January 2006].

Mbakwem, J.N (2005). Curriculum implementation \& instruction. Owerri: UPTHRUST.

Naris SN, Ukpere WI. 2012. Evaluation of human resource development and training at a higher educational institution in Namibia. African Journal of Business Management, 6(49): 11859-11864.

Nesbit, R., Wallace J.D., Puga- lee, D. K., Miller, A-C. \& DiBiase W.J (Eds.) (2001). Developing teacher leaders: Professional development in science and mathematics. Columbus, $\mathrm{OH}$ : ERIC Clearinghouse for Science, Mathematics and Environmental Education. [ED 45103 13].

Olanijor, B. (2000). "ASUU agrees to resume talks with FG. Punch, 9 August 2000.

Onoyese, D. (1991). The system oriented leadership model in relationship to staff administration in task, performance in higher educational institution. In Edo and Delta States in Nigeria journal Education Vol. 2 (4).

Onyede, G. (1989) Discovering Teaching, Enquire. Lagos: $4^{\text {th }}$ Dimension Publishing Company, Ltd. Owerri North secondary schools. (School Administrators (Principal) 2011/2012).

Prasad, L.M. (2004). Principles and Practices of Management. New Delhi Sultan Chand.

Rao, V.S.P (2009). Organisational Behaviour. New Delhi: Excel Books.

Robins, S.P. \& Judge, T.A. (2009). Organizational Behaviour. Prentice Hall Inc.

Rosener, J. (1990). Ways women lead. Harvard Business Review, 68: 119-125.

Schriesheim, C. A. (1982) The Great High Consideration- High Initiating Structure Leadership Myth: Evi-dence on its Generalizability. The Journal of Social Psychology, April 1982, 116, pp. 221-228.

Sergiovanni T J. (2001) Leadership what's it is in it for the future [Online] Available: http://www.slideshare.net/charles.corn/sergiovanni1477182 [20 July 2012]

Sullivan, E. \& Decker, P. (1997). Effective leadership and management in nursing (4th ed). London: Addison Wesley Longman, Inc.

Ukpere, W.I. 2007. The functional relationship between globalisation, internationalisation, human resources and industrial democracy. PhD Thesis (CPUT).

Vain, R. (2000). Role playing method in the classroom. Chicago: Science Research Association. (Related project work, personal collection)

Zaky, L. (1998). Students teaching in the secondary school: A guide for effective practice. New York: Harcourt, Brace and World Inc. 